\title{
Patch test standard series recommended by the Brazilian Contact Dermatitis Study Group during the 2006-2011 period ${ }^{*}$
}

\author{
Bateria de testes padrão preconizada pelo Grupo Brasileiro de Estudos em \\ Dermatite de Contato: período de 2006 a 2011
}

\author{
Ida Alzira Gomes Duarte \\ Rosana Lazzarini ${ }^{4}$ \\ Paulo Carrara de Castro ${ }^{6}$
}

\author{
Greta Merie Tanaka² \\ Andressa Sato de Aquino Lopes
}

\author{
Nathalie Mie Suzuki ${ }^{3}$ \\ Beatrice Mussio Fornazier Volpini ${ }^{5}$
}

DOI: http://dx.doi.org/10.1590/abd1806-4841.20132374

\begin{abstract}
A retrospective study was carried out between 2006-2011. Six hundred and eighteen patients with suspected allergic contact dermatitis underwent the standard patch test series recommended by the Brazilian Contact Dermatitis Research Group. The aim of our study was to evaluate the variation of positive patch-test results from standard series year by year. The most frequently positive allergens were: nickel sulfate, thimerosal and potassium bichromate. Decrease of positive patch-test results over the years was statistically significant for: lanolin $(p=0.01)$, neomycin $(p=0.01)$ and anthraquinone $(p=0.04)$. A follow-up study should be useful in determining which allergens could be excluded from standard series, as they may represent low sensitization risk.

Keywords: Allergens; Dermatitis, allergic contact; Dermatitis, contact; Patch tests; Skin tests
\end{abstract}

Resumo: Estudo retrospectivo foi realizado entre 2006 e 2011 em 618 pacientes com hipótese diagnóstica de dermatite de contato submetidos à bateria padrão de testes de contato preconizada pelo Grupo Brasileiro de Estudos em Dermatite de Contato com o objetivo de avaliar a variação, a cada ano, da frequência de positividade para as substâncias da bateria. Os principais sensibilizantes foram sulfato de níquel, timerosal e bicromato de potássio. As substâncias com diminuição da frequência de sensibilização estatisticamente significante foram lanolina $(p=0,01)$, neomicina $(p=0,01)$ e antraquinona $(p=0,04)$. A continuação deste trabalho poderá contribuir para verificar aqueles componentes que poderão ser eliminados da bateria, por representarem pouco risco de sensibilização.

Palavras-chave: Alérgenos; Dermatite alérgica de contato; Dermatite de contato; Testes cutâneos; Testes do emplastro

Patch tests are used to confirm the diagnosis and investigate the etiology of allergic contact dermatitis (ACD).

A retrospective study was carried out at the Allergy and Phototherapy Sector of the Dermatology Clinic of Santa Casa de São Paulo, in the period from January 2006 to December 2011, with 618 patients with diagnostic hypothesis of ACD. The patients underwent the standard epicutaneous patch series recommended by the Brazilian Contact Dermatitis Research Group (Grupo Brasileiro de Estudos em Dermatite de Contato - GBEDC). ${ }^{1}$

The objective of the study was to evaluate the frequency variation of positive test results for substances present in the mentioned standard series, year by year, during the period studied.

The epicutaneous tests, manufactured by FDA Allergenic (Rio de Janeiro, Brazil) were applied to the

Received on 16.12.2012.

Approved by the Advisory Board and accepted for publication on 17.01.2013.

* Study carried out at the Clinica de Dermatologia da Santa casa de São Paulo - São Paulo (SP), Brazil.

Conflict of interest: None

Financial funding: None

MD, PhD in Medicine - Adjunct Professor at the School of Medicine, Santa Casa de São Paulo (FCMSCSP) and assistant at the Dermatology Clinic of the Fraternity of Santa Casa de São Paulo - São Paulo (SP), Brazil.

MD, Resident physician at the Dermatology Clinic of the Santa Casa de São Paulo - São Paulo (SP), Brazil.

MD, Specialization program student at the Dermatology Clinic of the Santa Casa de São Paulo - São Paulo (SP), Brazil.

MD, Master's degree in Medicine - Professor at Medicine School, Santa Casa de São Paulo (FCMSCSP) - São Paulo (SP), Brazil.

Undergraduate student of Medicine at the School of Medicine, Santa Casa de São Paulo (FCMSCSP) - São Paulo (SP), Brazil.

MD, PhD in Public Health from Universidade de São Paulo (USP). Assistant professor of the Department of Social Medicine, School of Medicine, Santa Casa de São Paulo (FCMSCSP) - São Paulo (SP), Brazil. 
back of the patients by means of FINN Chambers pads (Epitest Ltd, Oy, Finland). The reading was done 96 hours after application in order to avoid doubts about sensitization, as positive tests with intensity marked by two or three crosses were considered. The statistical analysis of data was done using the correlation test of Pearson (CP), considering data with $\mathrm{p}<0.05$ as having statistical significance.

There was predominance of the female gender in all of the studied years, totalling 195 men and 423 women. The predominant age group was the 30-49 years and 170 positive tests $(17.6 \%)$ were related to the professions of the patients.

The main ACD sites were the cephalic segment $(45.3 \%)$, followed by upper limbs $(39 \%)$, hands (35.6\%), lower limbs (28.64\%), feet $(20.71 \%)$ and torso $(15.86 \%)$.

The total number of positive tests every year varied from 90 to 220, totaling 966 in the studied period. The positive test/patient variation was between 0.98 and 2.47 during the analyzed years.

The substances that presented higher positivity were: nickel sulphate $(28.16 \%)$, thimerosal $(16.02 \%)$, potassium dichromate $(11.17 \%)$, cobalt chloride (10.52\%), fragrance mix $(8.74 \%)$, carba mix $(7.28 \%)$, neomycin $(7.28 \%)$, paraphenylenediamin $(6.96 \%)$, PPD-mix (6.63\%) and thiuram-mix (6.15\%). The remaining substances were positive in less than $5 \%$ of cases (Table 1).

Studies carried out in other communities and already published have shown that the main sensitizers were the same obtained in this investigation. ${ }^{1-6}$ Nevertheless, differences were observed in the sensitization rates for some of the substances tested. The nickel sulphate sensitization rate, for example, was $28.16 \%$ and frequency varied between $10.4 \%$ and $19 \%,{ }^{7-10}$ in European and American publications. In several communities there are regulations regarding the limit of nickel release from items that may get into prolonged and direct contact with the skin, which contributed to the low sensitization rates.

Thimerosal, despite having been removed from several topical preparations, had a higher sensitization rate than that referred in other studies. ${ }^{2-6}$ This is due to its presence in preparations like vaccines, contact lenses solutions and tattoo ink, which favors the contact of the population with this substance.
The other sensitizers presented similar frequencies to those observed in other publications. ${ }^{1-6}$

Table 2 shows the variation, year by year, of standard series substance positivity. Some substances presented similar frequencies for the entire period studied, while others varied every year. Most of the substances presented a discrete tendency for the number of positive tests to decrease along the period. Three substances presented a diminished statistically significant sensitization rate: Lanolin $(p=0.01)$, Neomycin $(p=0.01)$, Anthraquinone $(p=0.04)$.

TABLE 1: Sensitization rate of standard series substances 618 patients - 2006-2011

\begin{tabular}{|c|c|c|}
\hline Substance & Total positive tests & $\%$ \\
\hline Nickel sulphate & 174 & 28.16 \\
\hline Thimerosal & 99 & 16.02 \\
\hline Potassium dichromate & 69 & 11.17 \\
\hline Cobalt Chloride & 65 & 10.52 \\
\hline Fragrance mix & 54 & 8.74 \\
\hline Carba mix & 45 & 7.28 \\
\hline Neomycin & 45 & 7.28 \\
\hline Paraphenylenediamin & 43 & 6.96 \\
\hline PPD mix & 41 & 6.63 \\
\hline Thiuram mix & 38 & 6.15 \\
\hline Ethylenediamine & 27 & 4.37 \\
\hline Promethazine & 21 & 3.40 \\
\hline Formaldehyde & 20 & 3.24 \\
\hline Mercaptobenzothiazole & 20 & 3.24 \\
\hline Balsam of Peru & 20 & 3.24 \\
\hline Parabens & 19 & 3.07 \\
\hline Hydroquinone & 19 & 3.07 \\
\hline Colophony & 17 & 2.75 \\
\hline Lanolin & 16 & 2.59 \\
\hline Quaternium 15 & 16 & 2.59 \\
\hline Kathon CG & 15 & 2.43 \\
\hline Benzocaine & 15 & 2.43 \\
\hline Nitrofurazone & 14 & 2.27 \\
\hline Turpentine & 11 & 1.78 \\
\hline Quinoline mix & 10 & 1.62 \\
\hline Propylene glycol & 10 & 1.62 \\
\hline Epoxi resin & 9 & 1.46 \\
\hline P-tertiary Buthylphenol & 5 & 0.81 \\
\hline Irgasan & 5 & 0.81 \\
\hline Anthraquinone & 4 & 0.65 \\
\hline TOTAL PATIENTS & 618 & \\
\hline
\end{tabular}


TABLE 2: Sensitization rate of standard series substances per year - from 2006 to 2011

\begin{tabular}{|c|c|c|c|c|c|c|c|c|}
\hline & $2006(n=89)$ & $2007(n=100)$ & $2008(n=113)$ & $2009(n=126)$ & $2010(n=98)$ & $2011(n=92)$ & TOTAL $(n=618)$ & Pearson's correlation \\
\hline Nickel Sulphate & 24 & 27 & 34 & 43 & 23 & 24 & 175 & $-0.1(p=0.8)$ \\
\hline Thimerosal & 25 & 6 & 17 & 22 & 18 & 11 & 99 & $-0.3(p=0.5)$ \\
\hline Potassium Dichromate & 19 & 13 & 7 & 14 & 10 & 6 & 69 & $-0.7(p=0.1)$ \\
\hline Cobalt Chloride & 15 & 5 & 10 & 14 & 11 & 11 & 66 & $-0.1(p=0.8)$ \\
\hline Fragrance mix & 6 & 2 & 13 & 10 & 7 & 8 & 56 & $0.4(p=0.3)$ \\
\hline Carba mix & 18 & 5 & 5 & 7 & 6 & 5 & 46 & $-0.6(p=0.1)$ \\
\hline Neomycin & 14 & 12 & 6 & 8 & 5 & 0 & 45 & $-0.9(p=0.01)$ \\
\hline Paraphenylenediamin & 4 & 10 & 4 & 9 & 8 & 7 & 42 & $0.3(p=0.5)$ \\
\hline PPD mix & 18 & 1 & 12 & 3 & 6 & 1 & 41 & $-0.6(\mathrm{p}=0.1)$ \\
\hline Thiuram mix & 16 & 3 & 1 & 6 & 9 & 4 & 39 & $-0.4(p=0.4)$ \\
\hline Ethylenediamine & 4 & 4 & 2 & 9 & 5 & 3 & 27 & $0.1(p=0.3)$ \\
\hline Promethazine & 2 & 6 & 2 & 6 & 3 & 3 & 22 & $-0.3(p=0.4)$ \\
\hline Formaldehyde & 7 & 3 & 4 & 2 & 6 & 1 & 23 & $-0.4(p=0.3)$ \\
\hline Mercaptobenzothiazole & 7 & 3 & 3 & 1 & 6 & 1 & 21 & $-0.5(p=0.3)$ \\
\hline Balsam of Peru & 2 & 0 & 3 & 8 & 1 & 3 & 17 & $0.1(p=0.7)$ \\
\hline Parabens & 3 & 3 & 7 & 1 & 8 & 2 & 24 & $0.9(p=0.8)$ \\
\hline Hydroquinone & 7 & 1 & 0 & 4 & 7 & 0 & 19 & $-0.2(p=0.6)$ \\
\hline Colophony & 4 & 1 & 3 & 5 & 3 & 1 & 17 & $-0.9(p=0.01)$ \\
\hline Lanolin & 4 & 3 & 3 & 5 & 1 & 1 & 17 & $-0.3(p=0.4)$ \\
\hline Quaternium 15 & 7 & 1 & 2 & 2 & 4 & 0 & 16 & $-0.5(p=0.2)$ \\
\hline Kathon CG & 0 & 1 & 1 & 1 & 9 & 2 & 14 & $0.2(p=0.6)$ \\
\hline Benzocaine & 3 & 0 & 1 & 6 & 3 & 3 & 16 & $0.5(p=0.2)$ \\
\hline Nitrofurazone & 3 & 1 & 1 & 5 & 4 & 0 & 14 & $-0.09(p=0.8)$ \\
\hline Turpentine & 2 & 0 & 2 & 6 & 1 & 0 & 11 & $-0.1(p=0.7)$ \\
\hline Quinoline mix & 0 & 2 & 0 & 0 & 1 & 1 & 4 & $0.0(p=1.0)$ \\
\hline Propylene glycol & 2 & 2 & 5 & 3 & 1 & 2 & 15 & $0.1(p=0.7)$ \\
\hline Epoxi resin & 0 & 3 & 1 & 4 & 2 & 1 & 11 & $-0.3(p=0.4)$ \\
\hline P-tertiary Buthylphenol & 2 & 0 & 1 & 0 & 1 & 1 & 5 & $-0.3(p=0.8)$ \\
\hline Irgasan & 1 & 1 & 0 & 0 & 3 & 0 & 5 & $0.04(p=0.4)$ \\
\hline Anthraquinone & 1 & 1 & 1 & 1 & 0 & 0 & 4 & $-0.8(p=0.04)$ \\
\hline TOTAL POSITIVE & 220 & 120 & 151 & 205 & 182 & 102 & 980 & \\
\hline TESTS & & & & & & & & \\
\hline
\end{tabular}

It is concluded that the standard patch test series was relatively uniform for studied years and only three substances had statistically significant decrease in positivity.

Nevertheless, the number of positive tests for each substance was small, so that the continuation of this investigation might contribute to the evaluation of the main sensitizers in the population studied and also verify which components might be eliminated from the series for presenting ever lower sensitization rates, representing a low risk for ACD. 


\section{REFERENCES}

1. Contact Dermatitis Brazilian Studying Group. Multicentric study for the development of a standard Brazilian patch test series. An Bras Dermatol. 2000:75:147-56.

2. Rodrigues DF, Neves DR, Pinto JM, Alves MF, Fulgêncio AC. Results of patch-testsfrom Santa Casa de Belo Horizonte Dermatology Clinic, Belo Horizonte, Brazil, from 2003 to 2010. An Bras Dermatol. 2012;87:800-3.

3. Zug KA, Warshaw EM, Fowler JF Jr, Maibach HI, Belsito DL, Pratt MD, et al. Patchtest results of the North American Contact Dermatitis Group 20052006.Dermatitis. 2009;20:149-60.

4. Thyssen JP, Linneberg A, Menné T, Johansen JD. The epidemiology of contact allergy in the general population - prevalence and main findings. Contact Dermatitis. 2007;57:287-99.

5. Uter W. La epidemiología de la alergia de contacto en Europa. Situación actual y perspectivas Actas Dermosifiliogr. 2011;102:4-7.

6. Bordel-Gómez MT, Miranda-Romero A, Castrodeza-Sanz J. Epidemiología de la dermatitis de contacto: prevalencia de sensibilización a diferentes alérgenos y factores asociados. Actas Dermosifiliogr. 2010;101:59-75.

7. Rui F, Bovenzi M, Prodi A, Fortina AB, Romano I, Peserico A, et al. Nickel, cobalt and chromate sensitization and occupation. Contact Dermatitis. 2013;68:23-31.

8. Rui F, Bovenzi M, Prodi A, Belloni Fortina A, Romano I, Corradin MT, et al. Nickel, chromium and cobalt sensitization in a patch test population in north-eastern Italy (1996-2010). Contact Dermatitis. 2013;68:23-31.

9. Hamann D, Hamann C, Li LF, Xiang H, Hamann K, Maibach H, et al. The sino-american belt study: nickel and cobalt exposure, epidemiology, and clinical considerations. Dermatitis. 2012;23:117-23.

10. Thyssen JP, Ross-Hansen K, Menné T, Johansen JD. Patch test reactivity to metal allergens following regulatory interventions: a 33-year retrospective study Contact Dermatitis. 2010;63:102-6.

\author{
MAILING ADDRESS: \\ Ida Alzira Gomes Duarte \\ Rua Cesário Motta Júnior, 112 \\ Vila Buarque \\ 01221-020 - São Paulo - SP \\ Brazil \\ E-mail:idaduarte@terra.com.br
}

How to cite this article: Duarte IAG, Tanaka GM, Suzuki NM, Lazzarini R, Lopes ASA, Volpini BMF, Castro PC. Standard patch test series recommended by the Brazilian Contact Dermatitis Study Group during the 2006-2011 period. An Bras Dermatol. 2013;88(6):1015-8. 